\title{
ТРАНСФОРМАЦИЯ СЕРОСОДЕРЖАЩИХ ГЕТЕРОЦИКЛОВ НА ПРИМЕРЕ ПРОИЗВОДНЫХ ТИАЗОЛИДИН-4-ОНА, ИЗУЧЕНИЕ СТРОЕНИЯ, ФИЗИКО-ХИМИЧЕСКИХ СВОЙСТВ И БИОЛОГИЧЕСКОЙ АКТИВНОСТИ
}

\author{
А.Ю. Симонов, И.Б. Левшин \\ ФГБНУ «Научно-исследовательский институт по изысканию новых антибиотиков \\ им. Г.Ф. Гаузе»,119021, Россия, г. Москва, ул.Большая Пироговская, 11, стр.1.
}

DOI: 10.19163/MedChemRussia2021-2021-41

E-mail: a.yu.simonov@gmail.com

Исследование реакционной способности и трансформации полифункциональных гетероциклических систем была, есть и остаётся одним из важных направлений органической химии. Изучение строения и свойств продуктов трансформации гетероциклов, протекающих под действием различных факторов, имеют большую практическую пользу и позволяют осуществлять синтез производных, получение которых прямыми способами значительно затруднено.

Изучена трансформация тиазолидиновых производных, осуществлён целенаправленный синтез серий новых гетероциклических систем и соединений на основе молекулы тиазолидин-2,4-диона[1-4]. Изучены новые пути трансформации тиазолидинового цикла с образованием ранее неописанных гетероциклических систем. Исследовано двойственное направление реакций гетероциклической системы в различных условиях синтеза.

На схеме представлен способ получения производного 3-оксотиоморфолина 4, выявленный при попытке встречного синтеза производного тиазолидина 2. Нами также показано влияние растворителя на направление реакции.<smiles>[R]c1ccc(/C=C2\SC(=O)NC2=O)cc1</smiles><smiles>[R]c1ccc(/C=C2\SC(=O)N(CCBr)C2=O)cc1</smiles>

3

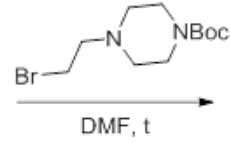

R<smiles>[R]c1ccc(/C=C2\SC(=O)N(CCN3CCN(C(C)=O)CC3)C2=O)cc1</smiles><smiles>[R]c1ccc(/C=C2\SCCN(C(=O)N3CCN(C(=O)OC(C)(C)C)CC3)C2=O)cc1</smiles>

\section{Литература}

[1] F. C. Brown,Chem.Rev.1961, 61, 463-521.

[2] S.P.Singh, S. S. Palmar, K. Raman and V/ L. Stenberg. Chem.Rev.,1981, 81, 175-203.

[3] R.B.Lesyk and B.S.Zimenkovsky,Current OrganicChemistry,2004, 8, 1547-1577.

[4] D.Kaminskyy, A.Kryshchyshyn, andR.Lesyk, European Journal of Medicinal Chemistry, 2017, 140, 542-594. 